\title{
Comparison of the Outdoor Activities Level in Selected Countries
}

\author{
Maroš Brodanský
}

University J.E.Purkyně, Czech Republic

Pasteurova Street 1, 40096 Ústí nad Labem

E-mail: marosbrodansky@gmail.com

\begin{abstract}
This paper considers the dynamics of recreation development in modern conditions. Present research displays the differences in approach to learning and developing activities between the two countries in the European Union (for example, the Kingdom of Spain and the Czech Republic), as well as between these countries and Russia

Keywords: outdoor activities; entertainment; education systems; the European Union.
\end{abstract}

\section{Introduction}

For Adults nature and open air appear as perfect place for relax and active leisure and as a natural playground for children. We came from nature to the houses and towns, but now we feel like returning back to nature to feel the air, freedom and enjoy the free time. Of course outdoor activities have long history, but currently one can feel the growing interest towards OA in education, leisure, therapies and commercial spheres. The commercial sphere of outdoor activities is one of the most fast-growing sectors of domestic and international tourism.

The theme choice was defined by lack of research in this field and difficulty to find some sources especially about level of outdoor activities or information about OA in educational systems.

The present research displays differences between two countries in European union (Kingdom of Spain and Czech republic) and between this countries and non-European county (Russian Federation)

\section{Results}

Index

- Definition of outdoor activities (OA)

- OA influence on the state economy

- OA background in the selected counties

- Outdoor activities in educational system of selected countries

- Commercial sphere of OA in selected countries

- Leisure time and OA

- Comparison table of the OA levels in the selected countries

- Conclusion

- References

\section{Outdoor activities (OA)}

- Adventure Sports have been best defined as 'Outdoor Sports or Activities in which the participant competes in a natural environment, more against himself than against others. Although the terms are sometimes used interchangeably, Extreme Sport can be considered as a sub-category of Adventure Sport, as well as the terms 'Action Sport' and 'Adventurous Sport' are also used. http:// www.topendsports.com/ sport/ adventure/

- Outdoor activities are classified as leisure time activities conducted outdoors, connected with adventure or exploring and extreme factor.

Many of these sport disciplines are classified as extreme sports.

Eric Brymer, (2006) referred to 'true' extreme sports as a leisure or recreation activity where the most likely outcome of a mismanaged accident or mistake was death.

- It may seem that research studies have considered, perhaps naïvely, that extreme sports are just further along the risk continuum than high-risk sports. At the surface extreme sports do have similarities with many high-risk sports, for instance they are self-initiated, typically occur in the natural environment, and have limited outcome certainty. However, extreme sports differ from high-risk sports in that an ineffectively managed accident or mistake has the almost unavoidable potential for death where as for the high-risk activity the result is usually restricted to injury (Hunt, 1996, 1995). 
- Examples: diving, geocaching, canyoning, snow rafting, ski touring, backpacking, Jibbing, lososing, paragliding, kiting, etc.

\section{OA influence on the state economy.}

Cash flow supported by OA

- Travelling (In-out) - people are spending lots of money for travel tickets to try something new, or to do favorite activity in the world famous place, or just in better conditions, than in "backyard"

- Visas, taxes... - and money for administrative work(passports)

- Local facilities- higher profits for providers of accommodation, restaurants...

- Insurance - profits for insurance companies (higher insurance payment for ex.sports)

etc.)

- Specialized and common shops- sports equipments, clothing, additional stuff (cameras

- Culture and events - outdoor activities and active life can be lifestyle, but it is still interesting to see it from other site, amateurs interest can be much higher if they can just watch and are not obliged to participate. Film festivals on travelling and adventure are great money makers as competitions and exhibitions in some of OA disciplines perform as a "magnet" for visitors.

\section{Background of OA in Czech Republic}

In Slovakia there is a saying that each Czech man is waterman, it's a way express outdoor active character of the nation. Though there are only 11 millions habitants one can to meet them in every corners of the world looking for some adventure and extreme.

There are great sportsmen in different disciplines:

Ales Valenta-acrobatic ski jumps,

Adam Ondra- climbing,

Michael Beran- BMX,

Martin Štepanek - free diving

OA in educational system of Czech Republic

Elementary and High schools:

- 2 times a year obligatory outdoor training with games, competitions first aid training and basics of civil protection for students of elementary and highs schools.

- One time at elementary school and one time at high school obligatory ski course as a part of physical training education canoe, windsurf)

- There is obligatory swimming course at high school (5 days), it's popular to held it by the sea, so it's connected with travelling to other countries (cause Czechs don't have see) and can be classified as outdoor activity.

\section{OA at Czech universities}

Czech universities pay attention to OA education

- Optional ski course usually with credits value for all specializations

- For students of sport department it is obligatory to take ski and water courses.

The course of skiing is held twice. First week - cross country skiing and classical skiing, second week - snowboarding and carving. Upon completion of courses the student gets the certificate of "School skiing instructor "for non-commercial use.

- Within specialization of Outdoor activities future instructor of outdoor activities, animator, or mountain guide are taught.

- Universities where the OA studies are available:

Karlova University, Prag

J.E. Purkyne University, Usti nad Labem

Palacky University, Olomouc

\section{Leisure and commercial sphere of OA in Czech Republic}

- Scouting non-profit organizations offering year-round programs are leading among children leisure organizations.

- High level of OA in commercial sphere in spite of the fact that there are only 10,5 millions habitants 
experience)

experience agencies (offer short time trips and excursions focused on new exciting

adventure travel agencies( journeys to exotic countries with active programs)

I Individual guides (for example offering guiding services in high mountains)

Rentals - of equipments and gear

口 Ski instructors

Kingdom of Spain

- Summer OA are much more common due to natural conditions

- The conditions for summers sports attract many foreigners

- Great sport results in rock climbing, slack lining, triathlon...

OA in educational system of Spain

Elementary and high schools:

- OA are generally offered as an optional excursions, that is mostly initiative of some teachers who are glad to do something beyond the program for children leisure

- There is no obligatory outdoor training in Spanish school education system

OA at Spanish universities

- There are optional outdoor courses usually organized by commencial companies of OA

- The courses have credit value at some universities so the participence is considered as benefit for studies example: Sadus University Sevilla http://www.sadus.us.es/abonados/otrosprogramas/ actividades-en-el-medio-natural.html

- Students of physical training specializations are taught theoretical course "Active tourism and leisure", though the practical part is omitted and this subject is not part of physical education studies at all Universities

- There is a specialization of outdoor studies (BA.) in higher education (no university specialization) for example Malaga

http:// www.medac.es/ teco-tecnico-en-conduccion-de-actividades-en-el-medio-natural-IDC16. htm\#sthash.dNDAOw64.dpuf

\section{OA in leisure and commercial sphere in Spain}

- Leading children's organization in commercial sphere is scouting Inturjoven organizing camps for them http:/ / www.inturjoven.com/

- Generally trekking, surfing, biking and rock climbing are popular in Spain

- High level of OA in commercial sphere

Widespread: experience)

a experience agencies (offers short time trips and excursions focused on new exciting

a adventure travel agencies( journeys to exotic countries with active programs)

- Individual guides (offering guiding services in high mountains, canyoning, etc.)

- Rentals - of equipments and gear

Instructors of surfing, diving, kiting...

\section{Russia} disciplines

- Unlimited nature condition create great possibilities to develop any sport of OA

- The interest to OA as a hobby is lower

- Attraction OA gained more popularity

\section{OA in education system of Russia}

Schools:

- OA courses in leisure centers of tourism are available, but as in Spain, they are not obligatory and are not part of official education process

- "zbori" is basic military training conducted usually outdoors, the course is not always held outdoors and not all of the students are participating

- No obligatory outdoor training exist in schools of Russia

OA at Russian universities 
- Russian Institutions used to pay more attention to OA. They had good equipment accessible for students, organized trips to mountain regions as Kavkaz or rafting on the rivers. Few years ago due to the changes in educational system the OA courses were almost eliminated.

departments

- There are obligatory students physical training courses (e.g. trekking)

- Obligatory theoretical subjects on OA for tourism students and all spec. of sport

- Recreational Physical Training Specialization has some aspect of outdoor activity studies

- possibility to study type of Life long learning program after "specialization" studies, aimed to teach OA instructors

\section{Leisure OA in Russia}

- Tourism clubs are dominating among leisure organizations for children. They organize treks and competitions, teach how to survive in the wild

- year-round operation

\section{Commercial sphere of OA in Russia}

- High level of OA in commercial sphere

- Great number of little local companies offering off-road trips, excursions, etc. depending on countryside conditions. They usually offer the trips trough tour-operators

- Big agencies like Alpindustria operate all around the country and offer expeditions to Elbrus, other high mountains in Russia, or adventure programs.

Comparison table the OA levels in selected countries

$\square$-obligatory $\square$-available $\square$-not included in ed. sys.

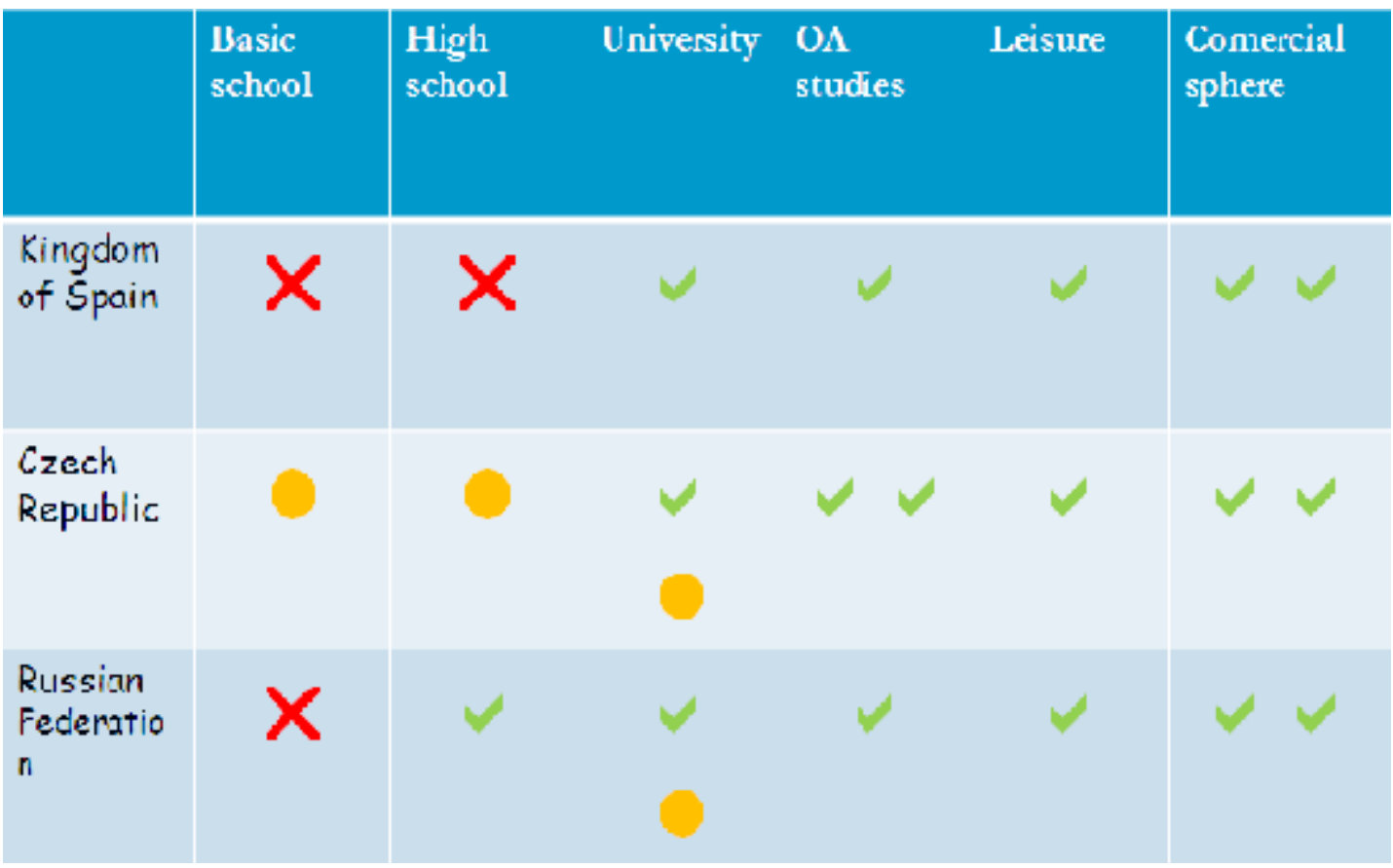

This research displays that outdoor activities are mostly promoted commercially. Great amount of travel agencies, experience agencies and mountain guides demonstrate high demand for outdoor activities as a way of spending free time.

There is a risk that commercial factor is developing faster than Universities study programs so as a result we have a "one way" specialist working in commercial sphere. Even if they are professionals in theirs disciplines and safety, probably they only took theoretical courses and their knowledge is not complex.

\section{Conclusion}

University study programs prepare experts of different activities and this process is more complex. As for safety study, it is connected with subjects like psychology, sociology.

Most probably Czech Republic shows higher interest in outdoor activities due to school educational system and obligatory courses, which teach children and foster their interest in OA. 
There is still some place for research in other spheres of OA, for example therapeutically, teambuilding and others connected with outdoor activities.

\section{References:}

1. Kurzy.cz, spol. s r.o., AliaWeb, spol. s r.o. http:// www.factivities.co.uk/

2. Consultations with teachers from sports departments of universities in Spain, Russia, Czechia http:// www.catalogs.com/info/ outdoor/ what-are- extreme-sports.html

3. Alice V. Khoshpakyants, Evgeniya V. Vidishcheva. Challenges of youth tourism // European Researcher. 2010. № 1, p.101-104.

4. other information sources in Spanish :

5. http:// fp.educaragon.org/guiaeducativa/ directorio modulos.asp?grafico $=$ \&idE $=2283 \&$ nombreC=Actividades $\% 20 \mathrm{f} \%$ EDsicas $\% 20 \mathrm{y} \% 20$ deportivas\&fotoC=familia gMedio.gif\&familia=si\& titulo=Formaci\%F3n\%20profesional\%20espec\%EDfica\%20-\%20Grado\%20medio

6. http:// www.futbolcarrasco.com/apartados/inef/4curso/3.pdf

7. http:// www.revistakronos.com/kronos/

8. http://actividadfisicaydeporte.uem.es/ es/trabajos-de-estudiantes/ actividades-en-elmedio-natural

9. http:// www.uva.es/ opencms/ contenidos/ serviciosAdministrativos/ extensionUniversitar ia/servicioDeportes/Campus/Campus_Universitario_Segovia/activsycursos/ Senderismo-y-

Actividades-en-el-Medio-Natural-.html?tamLetra=letra_grande

10. http:// www.sadus.us.es/abonados/otros-programas/programa-de-adherencia.html

11. http:// www.us.es/ estudios/grados/plan_ 154/asignatura_1540011\#programa

12. http:// www.medac.es/ teco-tecnico-en-conduccion-de-actividades-en-el-medio-natural-IDC16.htm

13. interesting pages in english

14. http://www.topendsports.com/sport/adventure/

15. http://www.oric.org.au/Research_Projects/Rsch_Extreme.html

16. http://www.ask.com/ question/ what-is-the-definition-of-extreme-sports

17. http://www.outdoor-sport-leisure.net/ extreme-sports.htm

\section{Сравнение уровня активного отдыха в отдельных странах}

Марош Бродански

Университет им. Яна Евангелиста Пуркине, г. Усти-над-Лабем, Чехия 40096, Усти-над-Лабем, ул. Пастерова, 1

E-mail: marosbrodansky@gmail.com

Аннотация. В статье проводится оценка динамики развития активного отдыха в современных условиях. Благодаря этим исследованиям можно увидеть различия в подходах к изучению и развитию активного отдыха между двумя странами в Европейском союзе (на примере Королевства Испания и Чешской Республики), а также между этими странами и Россией

Ключевые слова: активный отдых; развлечения; образовательные системы; Евросоюз. 